\title{
Different Façade Types and Building Integration in Energy Efficient Building Design Strategies
}

\author{
Muammer Yaman \\ Department of Architecture, Faculty of Architecture, Gazi University, Turkey
}

\begin{abstract}
Building façades play a major role in improving the effects of outdoor environment conditions on indoor comfort conditions. Façades, which are designed as energy efficiency, are created according to different performance parameters and can offer solutions appropriate for the climatic condition. This paper aims to describe and highlight the role of design and application determinants in building façade types according to energy efficiency in different climatic classes. For this purpose, 12 building façade types in different climate types were investigated and analyzed by a purposive or judgmental sampling technique. Façade analyses have been carried out by considering double skin, adaptive, photovoltaic panel, vertical green, media and structural membrane façades created as a result of developing technological opportunities. Balance of heat loss and gain, preventing overheating, providing daylight and natural ventilation, active and mechanical solutions for climate-sensitive, noise control, recycling and evaluating the initial investment cost are presented. With examinations, it has been determined that different façade systems are innovative construction systems in creating energy efficiency. It has been concluded that the effect of improving indoor comfort conditions of the building by controlling the outdoor environment conditions with the construction of different facade systems is very important in the architectural process. With the development of technology and smart systems, the impact of the façades on the climate analysis and energy efficient design strategies will be much more important in the future.
\end{abstract}

(C) 2021 Penerbit UTM Press. All rights reserved

\author{
Article History \\ Received: 11 December 2020 \\ Received in revised form: 10 March 2021 \\ Accepted: 18 March 2021 \\ Published Online: 30 April 2021

\section{Keywords:} \\ Façade systems, Façade materials, Building \\ envelope, Energy efficiency, Indoor comfort \\ conditions
}

\section{Corresponding Author Contact:}

muammeryaman@gazi.edu.tr

DOI: $10.11113 /$ ijbes.v8.n2.732

\section{Introduction}

In the process from past to present, there has been a great increase in the amount of energy used on a global scale. The increase in energy use causes the deterioration of the natural systems globally. Depletion of the existing energy resources makes it necessary to turn to alternative energy sources. The sustainability of human and nature harmony in order to meet the basic needs of the users is created by analyzing the energy productionconsumption at the optimum level. Especially when the energy uses of the century we live in is considered, the need for clean, inexhaustible and renewable energy resources is increasing day by day. Solar energy (passive, active, thermal and daylight), wind energy, biofuel energy, hydroelectric energy, ocean energy, geothermal energy and hydrogen energy are used as renewable energy sources (Lechner, 2015).

The most of the energy is consumed by buildings. Buildings aimed at providing the comfort conditions of the user are in an important position in terms of consuming energy. Considering the building life cycle, energy is an indispensable element for the building. There are differences in the increase in energy use in buildings and its global distribution. By following the traces of the past in sustainability and energy use, future evaluations and inferences are made. Recently, buildings that are self-sufficient within the framework of the building life cycle and independent buildings for energy have been designed and constructed (Oh et al., 2017). 
Building envelope is of great importance in evaluating energy use in the building. In balance of heat loss and gain, particular attention should be paid to façade (exterior wall, door and window and façade openings), roof / ceiling and floor elements in proportion to heat losses (Shoubi et al., 2018). Approximately $60 \%$ of the heat losses occurring throughout the building in the residential where the most intensive vital activities are carried out are due to façades, $25 \%$ due to roofs / ceilings and $15 \%$ due to floors (Figure 1). In this case, building façades, one of the components of the building envelope elements, are of great importance in creating and improving indoor comfort conditions and in sustainable design.

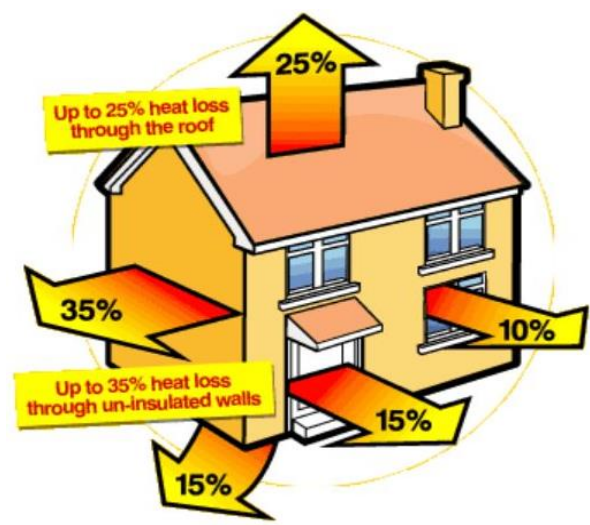

Figure 1. Distribution rate of heat losses in the building envelope (Haringey Council, 2017)

The evaluation of energy uses at the building and its systematic regulation in the building life cycle reveal the energy efficient building design process. In energy efficient building design, climatic data, context, building location, building form and façade components of the building can be taken as performance values. They are the building envelope that separate the outdoor environment and the indoor environment in the determination of performance properties, control the outdoor environment and enable the indoor comfort conditions to be design in the most appropriate solution. From this perspective, façade elements should be investigated in the design process and equipped with high performances in order to create the most appropriate values desired in the indoor environment (Manioglu and Koçlar Oral, 2010). In the design of the façade; the location of the façade, the location of the façade relative to other building façades, the orientation (direction) and form of the façade, the properties of the building façades, natural ventilation systems applied to the façade, and solar control systems applied to the façade are important parameters. In buildings, it is necessary to create a façade design that can adapt to the climatic conditions of the location, reduce energy and resource consumption and control outdoor environmental effects. The availability of different façade materials and advanced technical facilities play an important role in the development and advancement of façade construction systems.

In the historical process, depending on the technological possibilities and the development of building materials, the building façade systems have changed and transformed. When we systematically examine building façades according to the number of layers; we see it as single skin and double skin façades (Yesilli, 2016). However, in today's conditions, façade diversity has increased depending on different façade system solutions and performance requirements. Different façade configurations have been created as developed double skin, adaptive, photovoltaic panel, vertical green, media, structural membrane façades. Different performance requirements are revealed in the energy efficient use of façades with different design processes according to different climate types. In the scope of the literature, the efficiency obtained from the façades in energy efficient façade designs; climate data are shaped according to indoor comfort conditions and façade formation. Recently, buildings are created with Virtual Reality (VR) and Virtual Design and Construction (VDC) concepts are obtained. Simulations are used by means of Building Information Modelling (BIM) systems that develop with the stratification of performance evaluations and building integrated systems and future usage scenarios are estimated. Along with Virtual Reality (VR), optimization models for different parameters are also used for façade performance data (Loonen et al., 2014; Si et al., 2016; Huang and Niu, 2016; Giuda et al., 2019).

In this paper, the design and application of different facade types in different climatic zones are emphasized. Study has been conducted through the responses of the facade types created according to different climate scenarios to indoor comfort conditions. Within the scope of the study, the contribution of the use of new generation materials and technologies on a global scale and the construction of energy efficient facade systems to the building has been analyzed and evaluated. As a result of the study, suggestions for energy efficient facade design strategies are presented.

\section{Literature Review}

Building envelope has a great effect on the creation of energy efficient building design. Precautions to be taken in the building envelope contribute to the creation of indoor comfort conditions. Precautions should be taken according to energy efficient building design strategies in the façade design, which are one of the most important components of the building envelope. There are some basic criteria for designing high performance and smart façades in terms of energy efficient buildings:

- The position of the building and the shape of the form according to the influence of the sun,

- Design of shading elements to control cooling and heating loads,

- Use of natural ventilation to increase air quality and reduce cooling loads,

- Minimizing the energy used for mechanical heating and cooling systems and artificial lighting by optimizing exterior wall insulation and natural lighting (Aksamija, 2015).

The most important factor in the creation of high performance façades is the correct determination of the climatic conditions and their transfer to the process in façade system designs. Climatic properties; it affects the energy control mechanisms in façade design, material and system selection and façade setup according to the interior performance requirements (Kumar and Raheja, 
2016) In general, there are performance characteristics expected from the façade according to heating and cooling-dominated climate, mixed climate types depending on climatic parameters (Table 1).

Table 1 Façade performance characteristics according to climate types (Aksamija, 2015)

\begin{tabular}{cl}
\hline Climate Type & \multicolumn{1}{c}{ Design Strategies in Sustainable Façades } \\
\hline Heating- & - Solar collection and passive heating: collection of solar heat through the building envelope. \\
dominated & - Heat storage: storage of heat in the mass of the walls. \\
Climates & - Daylight: use of natural light sources and increased glazed areas of the façade, use of high-performance \\
& glass, and use of light shelves to redirect light into interior spaces. \\
\hline & - Solar control: protection of the façade from direct solar radiation through self-shading methods \\
Cooling- & - Reduilding form) or shading devices. \\
dominated & opaque façade elements) or conduction (by using shading devices). \\
Climates & - Cooling: use of natural ventilation where environmental characteristics and building function permit. \\
& - Daylight: use of natural light sources while minimizing solar heat gain through use of shading devices \\
& and light shelves. \\
\hline Mixed & - Solar control: protection of façade from direct solar radiation (shading) during warm seasons. \\
Climates & - Solar collection and passive heating: solar collection during cold seasons. \\
& - Daylight: use of natural light sources and increased glazed areas of the façade with shading devices. \\
\hline
\end{tabular}

When the performance parameters of energy efficient building design strategies are considered through the façade systems, system designs of different qualities can be created. Passive systems, active systems and mixed systems (hybrid systems) are examples of system configurations.

Passive systems; are self-operating systems for the conservation and use of energy during the building life cycle. In passive systems, there is no need for energy in the design principles for the use of existing energy in natural resources (Altan et al., 2016). Design decisions are made to reduce heat losses for thermal comfort conditions and to prevent overheating in the interior within the framework of the precautions to be taken in passive systems in the façade installation. Designing shading elements according to the direction of the façades to provide natural light in the interior for optimum light control is frequently preferred in passive systems scale. The design of the parameters for removing the indoor exhaust air and ensuring the indoor air quality (IAQ) using pressure differences and wind are put forward on the basis of passive design strategies. At the same time, the provision of recyclable materials, initial investment cost and noise control mechanisms for the use of energy should be addressed in this regard. The development of material and system alternatives and widely used passive systems should be considered during the building design process and should be operated in integration with the building. As a result of the application of passive systems, different façade system proposals for heating, cooling and thermal energy storage emerge within the context of the building (Figure 2).

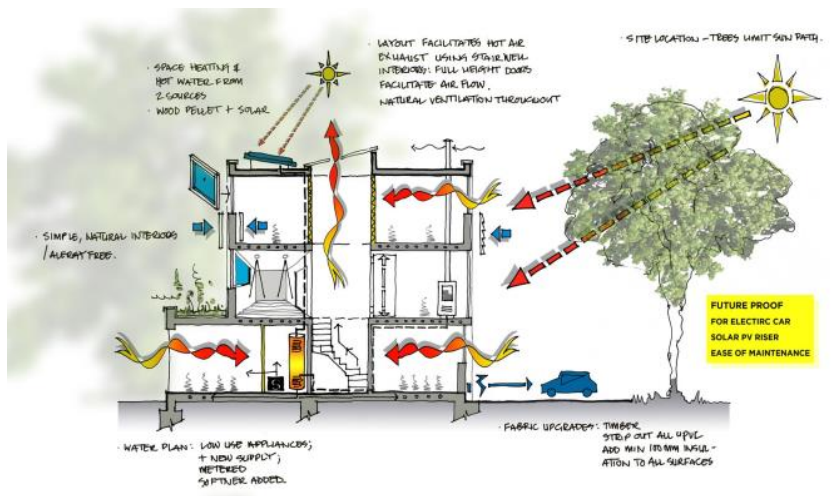

Figure 2 Designing passive system design strategies from the façade (Arch Monarch, 2020)

Active systems; include systems that contribute to energy efficient building design by taking part in the construction and operation of passive systems. These are the subsystems that make the control mechanism of the façade elements mobile when the climatic conditions are variable and the day-night / yearly climatic data are not stable. Active systems are known as adaptable, adaptive and kinetic façade systems in building façade systems. Selfextinguishing of lights, opening and closing of ventilation systems at different parts of the day, deflection of sunshade and photovoltaic elements on the façade and similar examples are used within the context of active systems (Kang et al., 2016). Having active systems creates a great performance value in energy efficient building design. The high initial investment cost is a design parameter that should be evaluated in today's buildings. In the evaluation of design and cost analysis, active systems should be considered as a future investment and cost-benefit analysis should be done in the long run. 
The increase in zero-energy building designs in the future cannot be built only with passive or active systems. The location of the design, the resources it uses, the cost of formation and emission regulations should be designed and operated in the most appropriate way (Torcellini, 2006). This situation directs the designer to use active and passive systems together, designing the building in an energy efficient way according to the desired performance values at the building scale. Hybrid (mixed) systems emerge with the use of active and passive systems integrated with each other. Active sun shading elements, steam cooling systems, elements for indoor use of wind for ventilation purposes are within the scope of hybrid systems.

\section{Different Façade Systems in Energy Efficient Building Design Strategies}

Different performance properties affect the design and application of building façades. Providing performance properties for energy efficient building design has an important role in terms of user comfort conditions. For this reason, stability, utility, beauty (firmitatis, utilitatis and venustatis) should be established as the basic properties expected from the building façade. When we look at the time period we live in, it is observed that different detail solutions are produced with different materials. The use of different materials has provided the advantages and disadvantages of facade construction systems. In this context, the project design team is expected to apply energy-efficient building design strategies and create the most appropriate solution suggestions in the process of designing building façades in the light of stability, utility and beauty principles.

\subsection{Double Skin Façades}

Double skin façades are passive façade systems formed by adding a second façade to the first façade of the building. In the system, which is divided into two as inner layer and outer layer, the cross section gap layer varies between $20 \mathrm{~cm}$ and $200 \mathrm{~cm}$. A continuous air circulation is provided from the gap. Air circulation can take place either naturally or mechanically. In the system, the outer layer is generally formed with a single transparent glass, while the inner layer is formed with low-e glasses or solar controlled glasses in order to provide heat control (Inan and Basaran, 2014). Double skin façade designs have advantages and disadvantages. Their main advantages are providing energy conservation, controlling daylight, reducing interior heating demands, providing ventilation, and providing appropriate acoustic comfort. On the other hand, the most important disadvantages of double skin façade designs are overheating of the gaps, high initial investment costs, and the need for maintenance and repair (Ahmed et al., 2016). One of the most important disadvantages of double skin facade designs is the risk of flame and smoke being carried to the top points quickly with the chimney effect during fire (stack effect).

Double skin façades have shown a lot of development space regardless of the building class. It provides the formation of high performance façades with the solution suggestions it brings to building materials and building performance. Double skin façades are classified according to the partitioning of the façade, type of ventilation and type of air flow (Figure 3). The expected double skin façade design should be made according to the requirements of the climate characteristics and indoor comfort conditions (Motevalian, 2014).

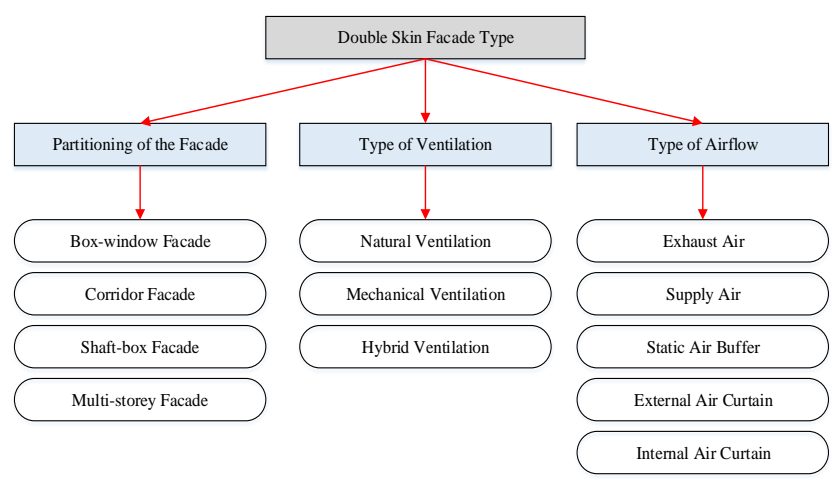

Figure 3. Double skin façade types (Motevalian, 2014)

\subsection{Adaptive Skin Façades}

These are active façade designs that are made to give a dynamic structure to the façade systems that separate the indoor and outdoor environment from each other and to give them the ability to move. In the design of movement systems, it is aimed to use the outdoor environment effects to create indoor comfort conditions in the most appropriate solution. In the regulation of performance parameters, there are heat, ventilation, vapour flow, precipitation control, use of sunlight, noise control, fire resistance, high stability and aesthetic (visual effect) purposes (Loonen et al., 2015) (Figure 4). Increasing the energy performance inside the building, ensuring daylight requirements and providing the highest level of thermal comfort are among the most basic requirements for façade design.

Movement ability on adaptive façades can be created with a manual system or can be designed with automatic-digital systems. However, the use of digital systems is a more appropriate solution for obtaining high efficiency and its continuity. At the same time, façade design solutions should be provided according to appropriate climatic conditions in building integration (Attia et al., 2018; Attia et al., (2020). According to the climate analysis at the initial stage of the project by the architect and the designer, active façades should be made by means of simulation programs in advance, and cost-benefit analyses should be determined in the future (Sharaidin and Salim, 2012). 


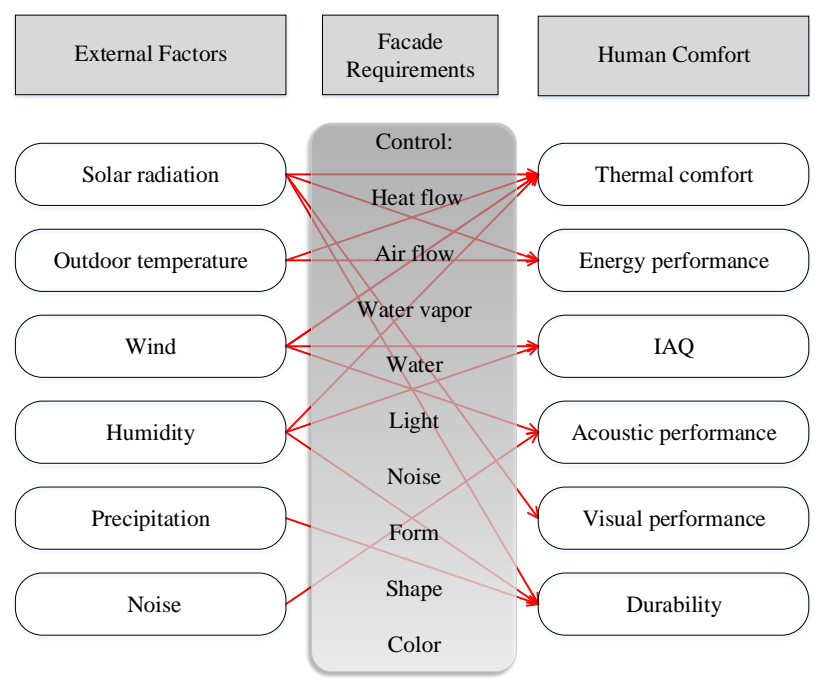

Figure 4 The relationship between the outdoor environment and indoor comfort conditions of adaptive façades (Aelenei et al., 2016)

\subsection{Photovoltaic Panel Façades}

When the use of photovoltaic panels in buildings is examined, it is generally seen on building roofs. Too much interaction with the sun has been an acceptable indicator of the use of the upper envelopes for this purpose. Today, when we look at the upper envelopes of the buildings, the use of panels on the façades has become widespread due to the change in the form of the roof types, the lack of sufficient space on the roof and the opening of the roof to occupant use. In façade use, the relationship with the sun should be properly designed, and elements that give various shade to the façade should be avoided. The relationship between climatic data and latitude should be considered as the most important parameters affecting the efficiency of photovoltaic panels used in façades. In the efficiency assessment of the use of photovoltaic panels, the annual sunshine duration of the region should be taken into account, and the cost-benefit analysis should be made within the framework of energy production (Grana and Haroldson, 2017).

In the use of photovoltaic panels, there are two different system proposals that can be adapted to the building (BAPV-Building Applied / Adopted / Added Photovoltaics) and building integrated systems (BIPV-Building Integrated Photovoltaics). However, higher efficiencies are obtained from photovoltaic panels that have been involved in the design process throughout the building system design and building life cycle, evaluated and transferred to the project (Snow and Prasad, 2011). Three different system proposals are developed for the use of building integrated systems on façades:

- Photovoltaic panels as façade exterior wall system,

- Photovoltaic panels as façade cladding material,

- Photovoltaic panels as additional elements in the façade.
Photovoltaic panel façades are great importance in finding energy generation in energy efficient building design strategies. Photovoltaic panels transform solar energy, which is an endless and renewable energy source, into electrical energy. As a response to the increasing energy demands in the world, photovoltaic panel types have increased, and a wide range of uses are offered to designers. It is possible to use photovoltaic panels in standard sizes as well as in special production types. (Pagliaro et al., 2010).

\subsection{Vertical Green Façades}

Vertical green façades are created with green façade systems with plants in the exterior wall system. Plants on the façade are used to control indoor comfort conditions together with environmental climatic conditions (Elgizawy, 2016). In the creation of the façade design, there are plants, habitat, carrier, filter layer, heat insulation layer, waterproofing layer, vapour barrier layer and exterior wall elements. Layers can be increased or decreased to appropriate design and application requirements.

The design of vertical green façades is especially preferred for the use of soil and plant roots for thermal insulation. The advantages of vertical green systems include reducing the urban heat island effect, increasing the outdoor air quality, providing an ecological balance and providing a habitat for various living organisms, assuming a protective role against rainwater and sun rays, and offering an architectural aesthetic value. It is seen as a disadvantage that vertical green systems require constant maintenance and seasonal changes for design and operation (Aygencel, 2011). Moreover, the initial investment costs should be optimized with the efficiency to be obtained in the process and planting should be made in accordance with the climate in which the building is located.

Different construction techniques are used in the design of vertical green façades:

- Green façades; They are the type of façade formed by wrapping the plant planted in the soil or in a pot on the exterior wall surface (Figure 5a).

- Planted walls; They are the type of façade where the exterior wall surface is used as a plant growing medium and the façade elements are directly active (Figure 5b).

- Living wall systems; They are the types of façade that are suitable for plant cultivation with different secondary elements in the exterior wall system (Figure 5c) (Perini, 2011). 


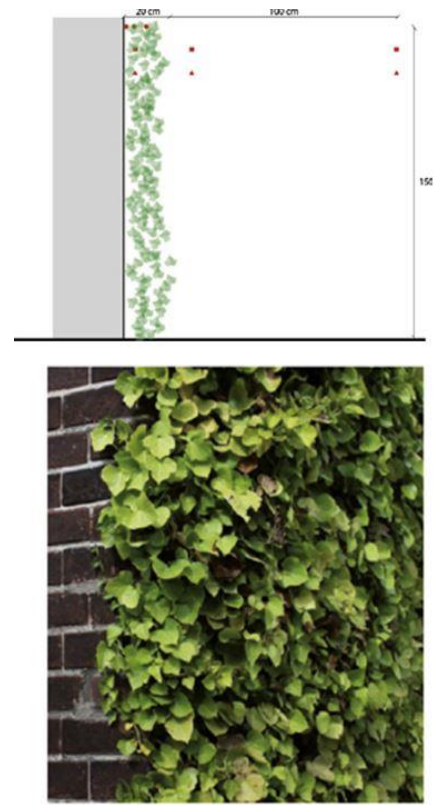

(a)

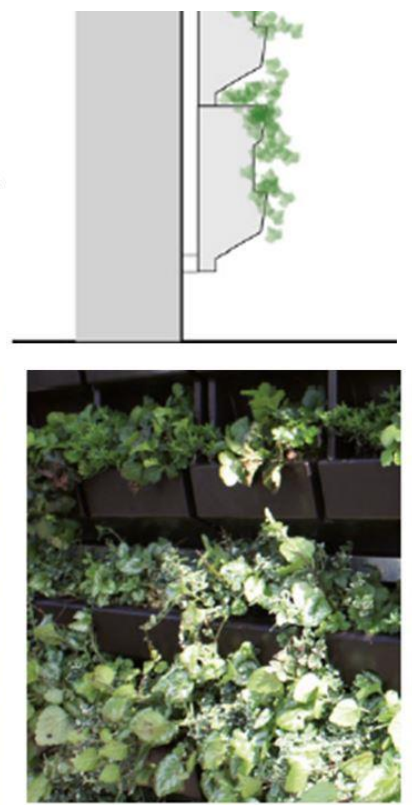

(b)

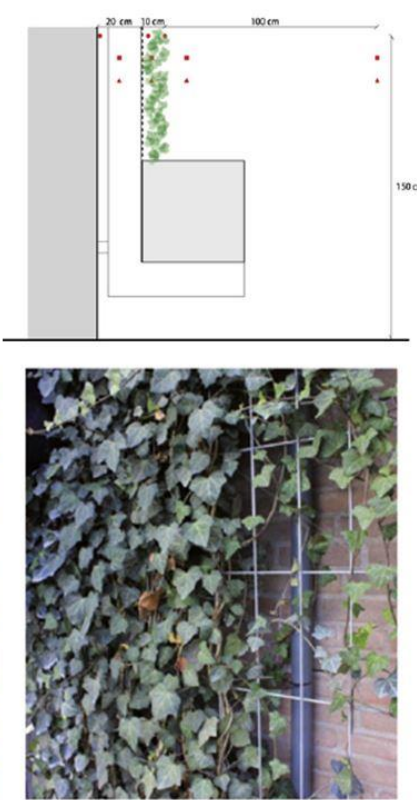

(c)

Figure 5 Design types and application examples of vertical green façades (Perini, 2011)

\subsection{Media Façades}

Media façades have been used as a communication tool in an architectural design from past to present. It has a great cultural potential, social and technological values along with its commercial, artistic and entertainment uses. While providing an interactive façade for building and city users, media façade components must be properly designed. On the other hand, media façade design components are important in terms of the carrier of the façade, the media façade content, the environment of the façade and the time factor (Moere and Wouters, 2012) (Figure 6).

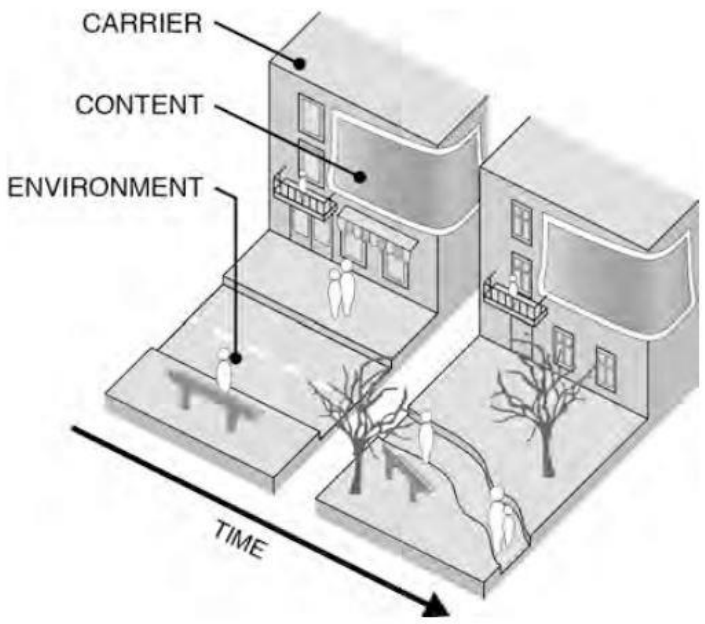

Figure 6 Design of media façades (Moere and Wouters, 2012)

When the purpose of use for media facade design are examined, energy efficient building design strategies should be evaluated. The design of media façades for lighting and visual comfort should be evaluated. Façade design should be planned to provide that visual effect and content resolution provide information transfer appropriately (Lee and Sul, 2017). The overheating risks of the lighting elements (point, strip, panel, etc.) used on the façade should be evaluated and investigated within the context of climate effects. Using kinetic elements, preferring double skin elements, and forming with shading elements, high efficiency is obtained from media façades within the scope of energy efficiency. In the design of media façades, the presence of photovoltaic panels used together with the media façades creates very useful products in terms of energy production. Designing with recyclable materials and using products compatible with technology increases the efficiency of the media façade system.

\subsection{Structural Membrane Façades}

In the light of developing technologies, a rapid development is seen in structural membrane designs on building façades. Structural membrane façades can be preferred for the design of the precautions that can be taken on the façades to create indoor comfort conditions (Figure 7). When we examine the structural membrane façades, we observe the façades constructed with two different materials:

- Textile façades, façades produced from a composite material consisting of woven elements coated on both sides,

- Foil façades, façades made of thin extruded materials less than 0.4 mm thick (Paech, 2016).

In structural membrane facades used for different purposes in buildings, fire resistance, UV transition resistance, life of the material, light transmittance are important parameters. Polyester (PES), polyvinylchloride (PVC), polytetrafluoroethylene (PTFE), are examples of textile façades as samples of structural membranes used in the façade. Ethylene tetrafluoroethylene (ETFE), ethylene chlorotrifluoroethylene (ECTFE) are samples of foil façades (Paech, 2016). 


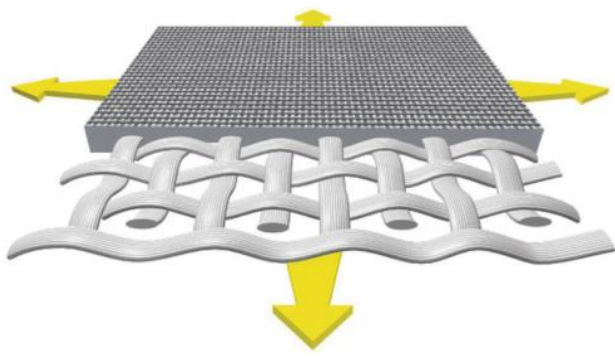

Figure 7 Components of structural membrane façades (Tensaform, 2020)

Structural membrane façades should be evaluated for building energy performance. Recently, it has been used as a single layer in the exterior wall system (especially in stadium structures) as well as a second layer. It has a great effect on reducing energy consumption, daylight control and natural lighting parameters. Playing a role in the improvement of indoor comfort conditions according to climatic conditions and the construction of elements that can be controlled in various designs are the primary parameters that should be evaluated in structural membrane façades (Chiu and Lin, 2015).

\section{Methodology}

Within the scope of the study, examinations were made on the types of façades that could respond to different outdoor environment conditions. Extensive literature research was carried out by considering double skin façades, adaptive façades, photovoltaic panel façades, vertical green façades, media façades, structural membrane façades as façade system design. The problem of this study is to determine whether there is a homogeneous distribution in the designs of façade types in the world. Using a purposive or judgmental sampling technique
(Taherdoost, 2016; Ghauri et al., 2020), a sample group was created for the application of different façade systems, regardless of the building class. The design and energy efficient building design strategies of 12 façades (two samples for each façade type / in different climate types) were evaluated.

As a result of the study, it has been revealed that different façade variations can be used in energy efficient building design and the effect of differences that may occur in terms of performance. Evaluations and inferences have been presented on the energy efficiency and user comfort for the use of façade variations.

\section{Data Analysis and Discussion}

Recently, as a result of the development of technological possibilities, alternative façade construction systems have increased according to environmental conditions and different climate types. In the field of façade design and application, different façade types have emerged to provide added value data to the building, to plan the cost-benefit analysis appropriately, to apply energy efficient building design for the designers. Two building examples from different climate types for different façade uses were taken and detailed investigations were made (Figure 8). In the light of the data available in the literature and obtained from reliable Internet sources, the analysis of the building façades was made. In the framework of the analysis, the name of the building, its designer, the year of construction, the number of floors, location, usage class, the climate class of the region and the explanations and evaluations regarding the energy efficient use of the facade systems were emphasized (Table 2). In the selected sample group, façade design decisions for different climate types were evaluated and general inferences were made.

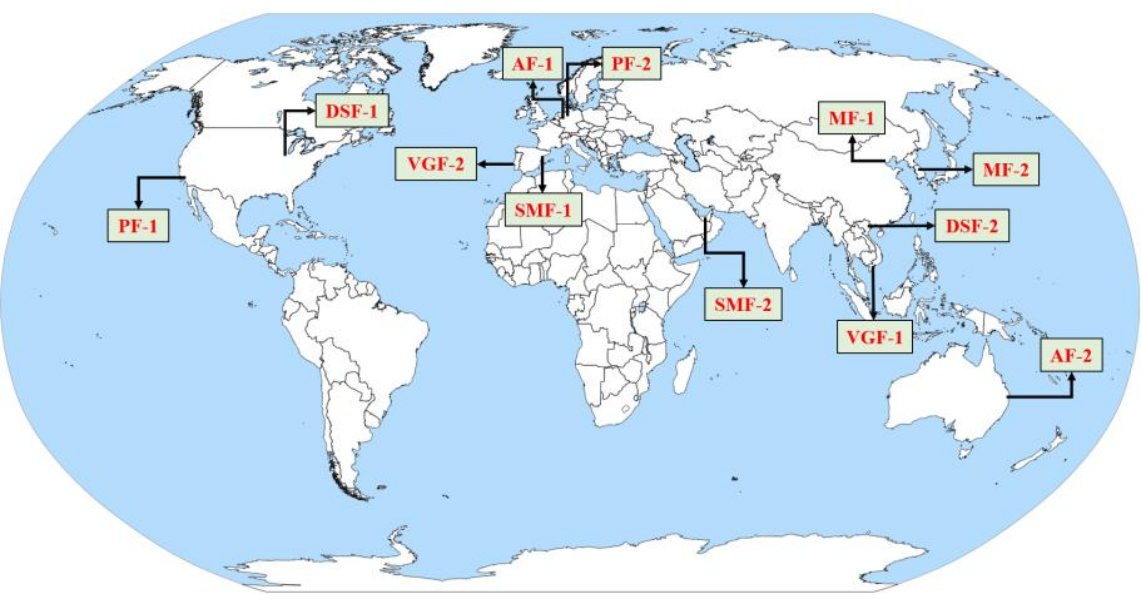

Figure 8 World distribution of the case study samples (Author, 2020)

In the light of the façade samples examined, the result is that different façade system solutions are used at a common point for energy efficient design strategies. The properties of different façade constructions, independent of height, construction year and building class, were examined in detail in the buildings investigated within the scope of energy efficient building design strategies. In the investigations made on different climate classes, transformations and integrated systems were determined to reach the common goal. In the GreenPix-Zero Energy Media Wall sample, a double skin façade, a photovoltaic panel façade and a media façade were designed and applied together. In the advanced stage of the study, the façade samples examined were analyzed according to their façade performances in energy efficient building design (Table 3). The following findings were obtained within the scope of the examined façade samples group: 
Table 2 Analysis of different façade systems in energy efficient building design strategies (Author, 2020)

\begin{tabular}{|c|c|c|c|c|c|c|c|}
\hline & $\begin{array}{c}\text { Façade Type } \\
\text { / Building Sample }\end{array}$ & $\begin{array}{l}\text { Designer / } \\
\text { Architect }\end{array}$ & $\begin{array}{l}\text { Year / } \\
\text { Floors }\end{array}$ & Location & $\begin{array}{l}\text { Building } \\
\text { Class }\end{array}$ & Climate Types & Explanations \\
\hline 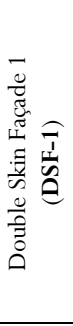 & $\begin{array}{l}\text { The Richard J. Klarchek } \\
\text { Information Commons }\end{array}$ & $\begin{array}{l}\text { Solomon } \\
\text { Cordwell } \\
\text { Buenz }\end{array}$ & $\begin{array}{c}2007 \\
/ \\
2 \text { Floors }\end{array}$ & $\begin{array}{l}\text { Illinois } \\
\text { / USA }\end{array}$ & $\begin{array}{l}\text { Office } \\
\text { Building }\end{array}$ & $\begin{array}{l}\text { Humid } \\
\text { Continental } \\
\text { Climate } \\
\text { (Dfa) } \\
- \\
\text { Köppen }\end{array}$ & $\begin{array}{l}\text { The double skin façade is used for solar } \\
\text { control through automation, as well as } \\
\text { increasing the indoor air quality. } \\
\text { Horizontal blinds hung on the façade } \\
\text { reduce the radiant effect and prevent } \\
\text { overheating, while at the same time } \\
\text { providing a homogeneous natural lighting } \\
\text { in the interior. The façade system design } \\
\text { provides an energy saving of } 52 \% \text { for } \\
\text { building (McLauchlan and Lavan, 2010). }\end{array}$ \\
\hline 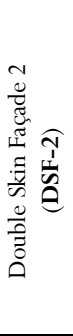 & $\begin{array}{c}\text { Brick Passive } \\
\text { Designed University }\end{array}$ & $\begin{array}{l}\text { Architects } \\
\text { TAISEI } \\
\text { DESIGN } \\
\text { Planners } \\
\text { Architects \& } \\
\text { Engineers }\end{array}$ & $\begin{array}{c}2017 \\
/ \\
2 \text { Floors }\end{array}$ & $\begin{array}{l}\text { Hung Yen } \\
\text { Province } \\
\text { / Vietnam }\end{array}$ & $\begin{array}{l}\text { Education } \\
\text { Building }\end{array}$ & $\begin{array}{l}\text { Humid } \\
\text { Subtropical } \\
\text { Climate } \\
\text { (Cwa) } \\
- \\
\text { Köppen }\end{array}$ & $\begin{array}{l}\text { The building façade designed as a shaft- } \\
\text { type façade from double skin façades } \\
\text { provides passive ventilation. The use of } \\
\text { cleaner and climatically attenuated air in } \\
\text { the interior improves the indoor comfort } \\
\text { conditions. Energy consumption was } \\
\text { aimed to be minimized with passive air } \\
\text { conditioning. Improving indoor air quality } \\
\text { has been a priority for the humid } \\
\text { subtropical climate (Archdaily, 2020a). }\end{array}$ \\
\hline 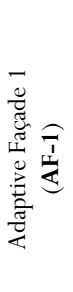 & Q1, ThyssenKrupp Quarter & $\begin{array}{c}\text { JSWD } \\
\text { Architekten, } \\
\text { Chaix \& } \\
\text { Morel et } \\
\text { Associés }\end{array}$ & $\begin{array}{c}2010 \\
/ \\
13 \text { Floors }\end{array}$ & $\begin{array}{l}\text { Essen } \\
\text { / Germany }\end{array}$ & $\begin{array}{l}\text { Office } \\
\text { Building }\end{array}$ & $\begin{array}{c}\text { Marine West } \\
\text { Coast Climate } \\
(\mathrm{Cfb}) \\
- \\
\text { Köppen }\end{array}$ & $\begin{array}{l}\text { The sunshade elements used in the façade } \\
\text { prevent overheating and glare of the sun's } \\
\text { rays in the interior. It rotates at an angle of } \\
90 \text { degrees horizontally and is positioned } \\
\text { to be sensitive to external sunlight. At the } \\
\text { same time, thermochromic glasses used as } \\
\text { facades offer various precautions for light } \\
\text { transmittance (Solla, 2010; Güncü and } \\
\text { Kurnuç Seyhan, 2013). }\end{array}$ \\
\hline 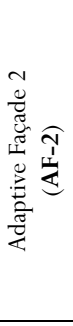 & $\begin{array}{c}\text { Brisbane Airport } \\
\text { Domestic Terminal }\end{array}$ & $\begin{array}{l}\text { Urban Art } \\
\text { Projects } \\
\text { (UAP) and } \\
\text { Ned Kahn }\end{array}$ & $\begin{array}{c}2012 \\
/ \\
8 \text { Floors }\end{array}$ & $\begin{array}{l}\text { Brisbane } \\
\text { / Australia }\end{array}$ & Carpark & $\begin{array}{l}\text { Humid } \\
\text { Subtropical } \\
\text { Climate } \\
(\mathrm{Cfa}) \\
- \\
\text { Köppen }\end{array}$ & $\begin{array}{l}\text { The façade is a 5,000 square meter kinetic } \\
\text { design formed by the combination of small } \\
\text { elements. } 118,000 \text { aluminium panels on } \\
\text { the façade move with the effect of the } \\
\text { wind. This effect of the façade filters the } \\
\text { light transmitted to the interior, while at } \\
\text { the same time providing a natural } \\
\text { ventilation. The façade system built } \\
\text { increases the indoor comfort quality } \\
\text { (Designboom, 2020). }\end{array}$ \\
\hline 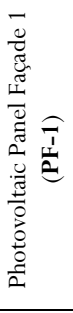 & $\begin{array}{c}\text { Green Dot Animo Leadership } \\
\text { High School }\end{array}$ & $\begin{array}{c}\text { Architects } \\
\text { Brooks }+ \\
\text { Scarpa } \\
\text { Architects }\end{array}$ & $\begin{array}{c}2013 \\
/ \\
2 \text { Floors }\end{array}$ & $\begin{array}{l}\text { Inglewood } \\
\text { / USA }\end{array}$ & $\begin{array}{l}\text { Education } \\
\text { Building }\end{array}$ & $\begin{array}{c}\text { Mediterranean } \\
\text { Climate } \\
\text { (Csa) } \\
- \\
\text { Köppen }\end{array}$ & $\begin{array}{l}\text { Photovoltaic panels placed on the southern } \\
\text { façade as a second layer generate } \\
\text { electricity from solar energy. Except for } \\
\text { certain transparencies, completely } \\
\text { photovoltaic panels are used as façade } \\
\text { finishing material. There is no urban } \\
\text { facility near the façade that would prevent } \\
\text { sunlight. } 650 \text { photovoltaic panels were } \\
\text { used (Archdaily, 2020b). }\end{array}$ \\
\hline 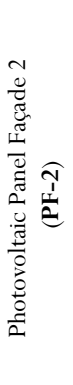 & Uat. & $\begin{array}{l}\text { Jourda \& } \\
\text { Perraudin }\end{array}$ & $\begin{array}{c}1999 \\
/ \\
2 \text { Floors }\end{array}$ & $\begin{array}{l}\text { Herne } \\
\text { / Germany }\end{array}$ & $\begin{array}{l}\text { Mixed Use } \\
\text { Building }\end{array}$ & $\begin{array}{c}\text { Marine West } \\
\text { Coast Climate } \\
(\mathrm{Cfb}) \\
- \\
\text { Köppen }\end{array}$ & $\begin{array}{l}\text { Photovoltaic panels placed in a single } \\
\text { façade layer were used in the roof and } \\
\text { façade integrated into the building. With } \\
\text { the transportation of the building with } \\
\text { light structural elements, the entire } \\
\text { building envelope was formed with } \\
\text { transparent elements. By using } \\
\text { photovoltaic panels in certain parts of } \\
\text { transparent elements, energy production- } \\
\text { based efficiency in indoor energy use has } \\
\text { been increased (Pasquay and Müller, } \\
\text { 2000; Pagliaro et al., 2010). }\end{array}$ \\
\hline
\end{tabular}


Table 2 Analysis of different façade systems in energy efficient building design strategies (cont.) (Author, 2020)

\begin{tabular}{|c|c|c|c|c|c|c|c|}
\hline & $\begin{array}{c}\text { Façade Type } \\
\text { / Building Sample }\end{array}$ & $\begin{array}{c}\text { Designer / } \\
\text { Architect }\end{array}$ & $\begin{array}{l}\text { Year / } \\
\text { Floors }\end{array}$ & Location & $\begin{array}{l}\text { Building } \\
\text { Class }\end{array}$ & Climate Types & Explanations \\
\hline 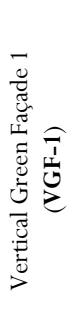 & 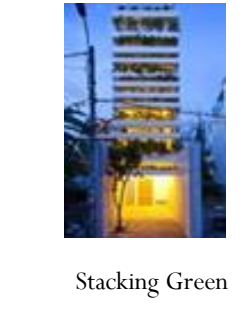 & $\begin{array}{l}\text { Vo Trong } \\
\text { Nghia, } \\
\text { Daisuke } \\
\text { Sanuki, } \\
\text { Shunri } \\
\text { Nishizawa }\end{array}$ & $\begin{array}{c}2011 \\
/ \\
3 \text { Floors }\end{array}$ & $\begin{array}{l}\text { Ho Chi Minh } \\
\text { / Vietnam }\end{array}$ & Residential & $\begin{array}{c}\text { Humid } \\
\text { Continental } \\
\text { Climate } \\
\text { (Dwb) } \\
- \\
\text { Köppen }\end{array}$ & $\begin{array}{l}\text { In the project, there is a green façade } \\
\text { design constructed in a narrow area of } \\
20 \mathrm{~m} \text { depth and } 4 \mathrm{~m} \text { width. Plants, } \\
\text { which allow for controlled temperate } \\
\text { ventilation, are transported through } \\
\text { prefabricated panels. At the same time, } \\
\text { plants that take sunlight into the building } \\
\text { in a controlled manner provide } \\
\text { insulation on the façade in terms of noise } \\
\text { control (Archdaily, 2020c). }\end{array}$ \\
\hline 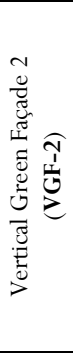 & 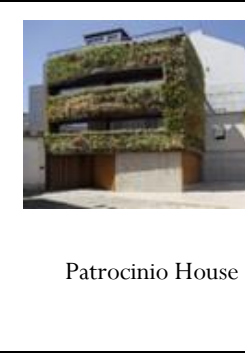 & $\begin{array}{c}\text { Architects } \\
\text { Luís Rebelo } \\
\text { de Andrade, } \\
\text { Manuel } \\
\text { Cachão Tojal, } \\
\text { Tiago Rebelo } \\
\text { de Andrade }\end{array}$ & $\begin{array}{c}2012 \\
/ \\
2 \text { Floors }\end{array}$ & $\begin{array}{l}\text { Lisbon } \\
\text { / Portugal }\end{array}$ & Residential & $\begin{array}{l}\text { Mediterranean } \\
\text { Climate } \\
\text { (Csa) } \\
- \\
\text { Köppen }\end{array}$ & $\begin{array}{l}\text { A green relationship was established with } \\
\text { the city by covering most of the façades } \\
\text { with plants. A suitable ecological habitat } \\
\text { has been created in which } 25 \text { different } \\
\text { plant species belonging to the Iberian } \\
\text { and Mediterranean regions are used in } \\
\text { close to } 4000 \text {. Plants that offer different } \\
\text { living spaces for small living organisms } \\
\text { provide different scents and clean air } \\
\text { quality to the building user (Williamson, } \\
\text { 2013). }\end{array}$ \\
\hline
\end{tabular}

Humid
Continental
Climate

GreenPix -

Zero Energy Media Wall

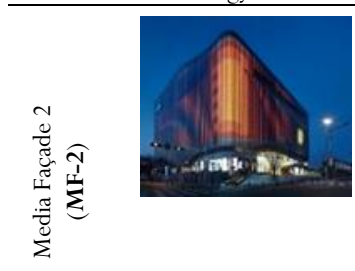

Galleria Centercity
The photovoltaic panels in the system, which works as a double skin façade designed as a media façade, are used to energy production. Obtaining the energy, it needs through panels reduced the cost of the façade and revealed the sustainability values of the building. The building has a façade layout in accordance with its purpose (Howard, 2008).

The façade is designed as a double skin. The outer layer is created in flat and angled combinations. It provides an

$\begin{array}{ll}\text { Humid } & \text { optical illusion on the façade. While the } \\ \text { Continental } & \text { DSF provides proper ventilation and }\end{array}$

Climate $\quad$ DSF provides proper ventilation and created with lighting fixtures placed on

the outer layer. Media façade and luminaires with higher resolutions create a dynamic facade design (Mandaglio, 2019; UN Studio, 2020)

The façade is created with ETFE panels that have swelling and deflation

Tropical and movement. The system working with Subtropical nitrogen fog and sensitive to sunlight Enric Ruiz- 2007 Geli - Barcelona / Mixed Use Steppe Climate Cloud 9 Floors Spain Building (Bsk) creates a sun filter. While ETFE panels act as a sunshade with their swelling, they provide thermal insulation with the

Köppen $\quad$ air buffers formed in the balloon.
Different dynamic façade design has been achieved (Eberl, 2016; Shahin, 2019).

PTFE elements have been added to the façade as a second layer. Elements with an active structure can move around the axis at certain periods. The shading elements provide solar control in the desert climate and at the same time allow cooling with the ventilated façade. These data help the cultivation of lawns by creating a special microclimate area indoors. In the evening, the façade elements can be illuminated with LED systems (Paech, 2016). 
- In order to create thermal control, precautions are taken against overheating of the interior environment in all façade types. Shading elements, moving (dynamic) systems and façades designed as secondary layers have been important design elements in preventing overheating. Providing internal air circulation and associating the circulation with the interior are among the façade design decisions generally. However, not all façade types can be used effectively in preventing heat losses. Climatic data affect façade control parameters in this context. Because of the desert climate in the Hazza Bin Zayed Stadium building, preventing heat losses is insignificant.

- In general, various precautions are taken on all façade types to provide lighting control. The healthy use of daylight is considered as an important parameter, especially in the framework of the buildings examined, its homogeneous distribution within the space. In lighting control, some shading element solutions have been offered within the scope of various suggestions on all façades in order to avoid the negative effects of direct sunlight and to protect against harmful ultraviolet rays. In addition, the balanced control of the lighting requirement and the overheating parameters has been resolved in the façade system design before the indoor space. The location, orientation and form of the building constitute the basic parameters that should be examined with the façade components in providing lighting control.

- In order to create the ventilation, solutions were presented to improve the indoor air quality (IAQ) in façade types. Especially on the façades that can be designed as the second layer, ventilation systems are considered and ventilation criteria are provided by creating buffer zones. Passive solution proposals were developed for different façade types for the extraction of indoor exhaust air and for the use of fresh air indoors. The façade elements play the most important role in creating a healthy interior environment. Monte-Cenis
Academy, Green Dot Animo Leadership HS, GreenPix buildings have not created high-performance relationships between facade and ventilation criteria.

- Creation of climate sensitive active solutions varies according to façade types. The preference rates are low in terms of managing and supervising the system control mechanism by an expert and creating problems for business continuity. Façade movement and dynamism are not considered in the R. J. Klarchek Information Commons, Stacking Green, Patrocinio House buildings.

- The changing situations in façade types for the creation of noise control, especially the sound of kinetic elements and the use of sound systems in media façades, have different characteristics. In the façade systems recommended in noisy spaces, it is necessary to create high efficiency façades for exterior wall sound insulation. It is important to consider plants as sound absorbers on vertical green façades in terms of noise control.

- The possibility of recycle is one of the main parameters that can be observed in all façade types examined. Choosing building materials that are based on building material life and that offer the possibility of reuse and recycle is a common idea adopted in different façade types.

- It is revealed that façade types are generally not suitable within the framework of initial investment cost eligibility. It is seen to high costs arise especially when compared with traditional façade design methods. However, within the framework of the building life cycle, cost-benefit analysis should be arranged according to energy use analysis. It was deemed appropriate to consider the initial investment costs as a whole within the framework of future costs and to make efficiency analysis.

Table 3. Analysis of different façade systems selected as sample group (Author, 2020)

\begin{tabular}{|c|c|c|c|c|c|c|c|c|}
\hline \multirow{3}{*}{$\begin{array}{l}\text { Samples of } \\
\text { Different } \\
\text { Façade } \\
\text { Systems }\end{array}$} & \multicolumn{4}{|c|}{ Passive Systems } & \multirow{3}{*}{$\begin{array}{l}\text { Active } \\
\text { Systems }\end{array}$} & \multirow{3}{*}{$\begin{array}{c}\text { Noise } \\
\text { Control }\end{array}$} & \multirow{3}{*}{$\begin{array}{c}\text { Recycle } \\
\text { Opportunity }\end{array}$} & \multirow{3}{*}{$\begin{array}{c}\text { Initial } \\
\text { Investment } \\
\text { Cost } \\
\text { Eligibility }\end{array}$} \\
\hline & \multicolumn{2}{|c|}{ Thermal Control } & \multirow{2}{*}{$\begin{array}{l}\text { Lighting } \\
\text { Control }\end{array}$} & \multirow{2}{*}{$\begin{array}{c}\text { Indoor } \\
\text { Air Quality } \\
\text { Control } \\
\text { (IAQ) } \\
\end{array}$} & & & & \\
\hline & $\begin{array}{l}\text { Reduce of } \\
\text { Heat Loss }\end{array}$ & $\begin{array}{c}\text { Reduce of } \\
\text { Overheating }\end{array}$ & & & & & & \\
\hline (DSF-1) & + & + & + & + & - & + & + & - \\
\hline (DSF-2) & - & - & - & + & + & - & + & + \\
\hline (AF-1) & + & + & + & + & + & Variable & + & - \\
\hline (AF-2) & - & + & + & + & + & Variable & + & - \\
\hline (PF-1) & + & + & + & - & + & - & + & - \\
\hline (PF-2) & + & + & + & - & + & + & + & - \\
\hline (VGF-1) & + & + & + & + & - & + & + & + \\
\hline (VGF-2) & + & + & + & + & - & + & + & + \\
\hline (MF-1) & + & Variable & + & - & + & Variable & + & - \\
\hline (MF-2) & + & Variable & + & + & - & Variable & + & - \\
\hline (SMF-1) & + & + & + & + & + & - & + & - \\
\hline (SMF-2) & - & + & + & + & + & - & + & - \\
\hline
\end{tabular}


Within the scope of the study, two different facade designs from each facade alternative in different climatic zones were considered and evaluated. However, the increase in sample numbers for future studies, changing climate scenarios and creating unique uses in different projects may differ in the use of façade alternatives in energy efficient building design strategies. In the light of climatic data, the basic requirement is that the façade design, which will be used in the creation of indoor comfort conditions, is designed and applied with high performance and smart façade systems.

\section{Conclusion}

Today, the need for clean and renewable energy is increasing day by day in order to increase the use of energy in buildings and to improve user comfort conditions. In this context, it has important tasks in providing indoor comfort requirement to the building envelope. It is expected that the building envelope will be designed to respond to outdoor environmental conditions (climatic data). Façade systems, especially as a building envelope, must be able to provide appropriate performance conditions at different times of the year. In energy efficient building designs, façade systems should be able to balance changing climatic conditions and user requirements and minimize energy consumption.

Different façade systems are being built with the recently developed technology and building materials. Double skin façades, adaptive façades, photovoltaic panel façades, vertical green façades, media façades and structural membrane façades are the main types of façade construction systems. Façades that offer different design and application possibilities are considered within the framework of suggestions that create energy efficient building design. The use of different façade construction systems provides the design to be created according to climatic data. Within the framework of energy efficiency; balancing heat losses and gains, preventing overheating, provide daylight control, increasing indoor air quality, developing active and mechanical solutions sensitive to climate are qualities that can be applied within the context of different façade systems. Moreover, providing noise control from different façade construction systems and the possibility of using recyclable materials increases the use of façade systems. It is known that the initial investment costs of different façade systems are generally high. However, in the building life cycle, it is necessary to make cost-benefit analyses of energy efficiency and to develop solutions according to the results. Energy efficient design, which is directly related to the building material and building system, can be created with active-passive solutions in different façade systems. The use of integrated systems for different façade systems to create climate sensitivity and indoor comfort conditions is important for active and passive systems to apply together to achieve a high performance façade. It is necessary to design façades that can respond to appropriate climatic conditions with the guidance of experts and façade consultants in the process of building and application the façade design system.

Energy efficient building design strategies, which are developing rapidly in the field of architecture in our country and in the world, are created by selecting materials that provide energy efficiency, high performance, recyclable materials and which are less harmful to the environment for designers. The construction of façade systems, which should be considered within the framework of sustainable architecture, helps the transfer of the three most basic concepts of architecture (stability, utility, beauty) to future generations. It is expected to create energy efficiency by designing facade systems according to the requirements of different interior and exterior environment created according to changing climatic conditions. Increasing the samples selected from different climate zones, differentiation of regional climate scenarios, changing climate data on a global scale and creating different designs specific to the buildings can show different approaches in defining and interpreting energy efficient facade systems. For future studies, researches are proposed on the design and implementation of energy efficient facade systems according to the changing climate scenarios on a regional and global scale, and their ability to respond to different performance criteria based on building usage class. In the future, it is a necessity and an indispensable design concept to design original and different facade systems in accordance with energy efficient design strategies, to create a sustainable world life and to provide values suitable for user comfort conditions.

\section{References}

Aelenei, D., Aelenei, L., \& Vieira, C. P. (2016). Adaptive Façade: Concept, Applications, Research Questions. Energy Procedia, 91: 269 275. doi.org/10.1016/j.egypro.2016.06.218

Ahmed, M. M. S., Abel-Rahman, A. K., Ali, A. H. H., \& Suzuki M. (2016). Double Skin Façade: The State of Art on Building Energy Efficiency. Journal of Clean Energy Technologies, 4(1): 84-89. doi:10.7763/JOCET.2016.V4.258

Aksamija, A. (2015). High-Performance Building Envelopes: Design Methods for Energy Efficient Façades. 4th BEST Conference Building Enclosure Science \& Technology (BEST4). Kansas City, USA.

Altan, H., Hajibandeh, M., Aoul, K., \& Deep A. (2016). Chapter 8-Pasive Design, ZEMCH: Toward the Delivery of Zero Energy. Springer, Switzerland.

Archdaily, (2020a). Brick Passive Designed University /TAISEI DESIGN Planners Architects \& Engineers. Retrieved December, 2020, from https: / / www.archdaily.com/877077/brick-passive-designed-universitytaisei-corporation

Archdaily, (2020b). Green Dot Animo Leadership High School / Brooks + Scarpa Architects. Retrieved December, 2020, from https://www.archdaily.com/340616/green-dot-animo-leadership-highschool-brooks-scarpa-architects

Archdaily, (2020c). Stacking Green / VTN Architects. Retrieved December, 2020, from https://www.archdaily.com/199755/stackinggreen-vo-trong-nghia

Archi Monarch, (2020). Passive Cooling. Retrieved December, 2020, from https://archi-monarch.com/passive-cooling/

Attia, S., Bilir, S., Safy, T., Struck, C., Loonen R., \& Goia, F. (2018). Current Trends and Future Challenges in the Performance Assessment of Adaptive Façade Systems. Energy \& Buildings, 179: 165-182. doi.org/10.1016/j.enbuild.2018.09.017 
Attia, S., Lioure, R., \& Declaude, Q. (2020). Future Trends and Main Concepts of Adaptive Façade Systems. Energy Science \& Engineering, 8: 3255-3272. doi.org/10.1002/ese3.725

Aygencel, M. (2011). Vertical Green Systems [in Turkish]. Master Dissertation, Karadeniz Technical University, Trabzon, Turkey.

Chiu, S. K., \& Lin, E. S. (2015). Tensile Membrane Façade: Performance Analysis of Energy, Daylighting and Material Optical Properties. 10th Conference on Advanced Building Skins, Bern, Switzerland.

Designboom, (2020). Brisbane Airport Kinetic Parking Garage Facade by Ned Kahn + UAP. Retrieved December, 2020, from https://www.designboom.com/art/brisbane-airport-kinetic-parkinggarage-façade-by-nedkahn-uap/

Eberl, A. (ed.) (2016). Energy Design Vol. IV/I-Adaptive Façade Systems. Graz University of Technology Institute of Buildings and Energy (IGE) Energy Design, Seminar.

Elgizawy, E. M. (2016). The Effect of Green Façades of Landscape Ecology. Procedia Environmental Science, 34: 119-130. doi.org/10.1016/j.proenv.2016.04.012

Ghauri, P., Gronhaug, K., \& Strange, R. (2020). Research Methods in Business Studies. Harlow, FT/ Prentice Hall, Fifth Edition, USA.

Giuda, G. M. D., Giana, P. E., Masera, G., Seghezzi, E., \& Villa V. (2019). A BIM-based Approach to Façade Cladding Optimization: Geometrical, Economic and Production Control in a DfMA Perspective. 2019 European Conference on Computing in Construction Chania, Crete, Greece.

Grana, P., \& Haroldson, C. (2017). Wall-Mounted Solar: A Rising Trend or Barely Hanging on? Yeni Enerji-Solar Power World, 60: 54-59.

Güncü, A., \& Kurnuç Seyhan, A. (2013). Günes Enerjisine Dayalı Yenilikçi Kinetik Yapı Kabugu Uygulamaları [in Turkish]. I. Uluslararası Mühendislik ve Fen Bilimlerinde Yenilikçi Teknolojiler Sempozyumu (ISITES2013), Sakarya, Turkey.

Haringey Council, (2017). Energy, Save Energy-Together We Can Make a Difference. Retrieved December, 2020, from https://www.haringey.gov.uk/environment-and-waste/goinggreen/energy

Howard, S. (2008). A Green Screen for Beijing, Architectural Record, 69 70

Huang, Y., \& Niu, J. (2016). Optimal Building Envelope Design Based on Simulated Performance: History, Current Status and New Potentials. Energy and Buildings, 117: 387-398. doi.org/10.1016/j.enbuild.2015.09.025

Inan, T., \& Basaran, T. (2014). A General Evaluation on Double Skin Facades [in Turkish], Megaron, 9(2): 132-142. doi:10.5505/MEGARON.2014.91885

Kang, J., Ahn, K., Park, C., \& Schuetze T. (2016). A Case Study on Passive vs. Active Strategies for an Energy-Efficient School Building Design. 8th Conference of the International Forum on Urbanism, Incheon, Korea.

Kumar, G., \& Raheja G. (2016). Design Determinants of Building Envelope for Sustainable Built Environment: A Review. International Journal of Built Environment and Sustainability, 3(2): 111-118.
Lechner, N. (2015). Heating, Cooling, Lighting Sustainable Method for Architect. Hoboken, John Wiley \& Sons, Inc., Fourth Edition, New Jersey, USA.

Lee, J. S., \& Sul, S. H. (2017). Media Façade and Design Identity of Buildings Based On Visual Density. International Journal of Asia Digital Art \&Design, 21(1): 49-55.

Loonen, R. C. G. M., Hoes, P., \& Hensen, J. L. M. (2014). Performance Prediction of Buildings with Responsive Building Elements: Challenges and Solutions. 2014 Building Simulation and Optimization Conference (BSO14), London, United Kingdom.

Loonen, R. C. G. M., Rico-Martinez, J.M., Favoino, F., Brzezicki, M., Menezo, C., La Ferla, G., \& Aelenei, L. (2015). Design for Façade Adaptability-Towards A Unified and Systematic Characterization. 10th Conference on Advanced Building Skins, Bern, Switzerland.

Mandaglio, M. (2019). Chameleon Building. IOP Conference Series: Earth and Environmental Science, 296, Milan, Italy.

Manioglu, G., \& Koçlar Oral, G. (2010). Ekolojik Yaklasımda Iklimle Dengeli Cephe Tasarımı [in Turkish], 5. Ulusal Çatı \& Cephe Konferansı, İmir, Turkey.

McLauchlan, D. J., \& Lavan, D. (2010). Richard J. Klarchek Information Commons Building: Chicago, IL, High Performing Buildings. Spring 2010.

Moere, A. V., \& Wouters, N. (2012). The Role of Context Media Architecture. PerDis, Portugal.

Motevalian, E. (2014). Double Skin Façades Performance: Effects on Daylight and Visual Comfort in Office Spaces. University of Southern California, Faculty of the USC School of Architecture, Master Thesis, Los Angeles.

Oh J., Hong T., Hakpyeong K., An J., Kwangbok J., \& Koo C. (2017). Advanced Strategies for Net-Zero Energy Building: Focused on the Early Phase and Usage Phase of a Building's Life Cycle. Sustainability, 9: 2272. doi.org/10.3390/su9122272

Paech, C. (2016). Structural Membranes Used in Modern Building Façades. Procedia Engineering, 155: 61-70. doi.org/10.1016/j.proeng.2016.08.007

Pagliaro, M., Ciriminna, R., \& Palmisano, G. (2010). BIPV: Merging the Photovoltaic with the Construction Industry. Progress in Photovoltaics: Research and Applications, 18: 61-72.

Pasquay, T., \& Müller, H. F. O. (2000). Academy Mont-Cenis: Planning of Natural Ventilation and Daylighting in A Large Microclimatic Envelope. World Renewable Energy Congress VI, Brighton, UK.

Perini, K., Othello, M., Fraaj, A. L. A., Haas E.M., \& Raiteri R. (2011). Vertical Greening Systems and the Effect on Air Flow and Temperature on the Building Envelope. Building and Environment, 46: 2287-2294. doi.org/10.1016/j.buildenv.2011.05.009

Shahin, H. S. M. (2019). Adaptive Building Envelopes of Multistory Buildings as an Example of High Performance Building Skins. Alexandria Engineering Journal, 58: 345-352. doi.org/10.1016/j.aej.2018.11.013

Sharaidin, K., \& Salim, F. (2012). Design Considerations for Adopting Kinetic Façades in Building Practice. In Digital Physicality| Physical Digitality: (eCAADe 2012), Czech Technical University, Faculty of Architecture. 
Shoubi, M. V., Shoubi, M. V., Bagchi, A., \& Barough, A. S. (2018). Reducing the Operational Energy Demand in Buildings Using Building Information Modeling Tools and Sustainability Approaches. Ain Shams Engineering Journal, 6: 41-55. doi.org/10.1016/j.asej.2014.09.006

Si, B., Tian, Z., Jin, X., Zhou, X., Tang, P., \& Shi X. (2016). Performance Indices and Evaluation of Algorithms in Building Energy Efficient Design Optimization. Energy, 114: 100-112. doi.org/10.1016/j.energy.2016.07.114

Snow, M., \& Prasad, D. (2011). Building-Integrated Photovoltaics (BIPV). Environment Design Guide, EDG 68, Royal Australian Institute of Architects.

Solla, I. F. (2010). Façades Confidential. Retrieved December, 2020, from http://façadesconfidential.blogspot.com/2010/12/thyssenkruppquarter-façades-giants.html

Taherdoost, H. (2016). Sampling Methods in Research Methodology; How to Choose a Sampling Technique for Research. International Journal of Academic Research in Management (IJARM), 5(2): 18-27. doi.org/10.2139/ssrn. 3205035

Tensaform, (2020). Asma Germe Sistemler [in Turkish]. Retrieved December, 2020, from http://www.tensaform.com/tr/anasayfa/

Torcellini, P., Pless, S., Deru, M., \& Crawley, D. (2006). Zero Energy Buildings: A Critical Look at the Definition. National Renewable Energy Laboratory, NREL Conference Paper, USA.

UN Studio, (2020). Galleria Centercity. Retrieved December, 2020, from https://www.unstudio.com/en/page/388/galleria-centercity

Williamson, C. (2013). A Plant-Covered Home: House Patrocinio by Rebelo De Andrade. Retrieved December, 2020, from https://designmilk.com/plant-covered-house-patrocinio-by-rebelo-de-andrade/

Yesilli, G. (2016). The Advanced Facade Systems in the Frame of Ecologic Energy Efficient Design, Changing According to Climatic Conditions and Foresight for the Future [in Turkish]. Master Dissertation, Gazi University, Ankara, Turkey. 